\title{
CANCUN-96 to Be Held in September
}

The International Materials Research Congress will be held September 1-6, at the Marriot Casa Magna in Cancún, México. The conference is organized by Academia Mexicana de Ciencia de Materiales, A.C.; Asociación Mexicana de Microscopía Electrónica, A.C.; and Sociedad Mexicana de Ciencia de Superficies y Vacío, A.C. Twenty-one symposia are scheduled:

- Symp. 1: Research and Applications of Advanced Nanostructured Materials;

- Symp. 2: Advances on Electron Microscopy on the Characterization of Materials; - Symp. 3: International Symposium on Solar Energy Materials;

- Symp. 4: Optoelectronic Materials: Trends and Applications;

- Symp. 5: Preparation of Materials by Soft Chemistry;

- Symp. 6: Developments in Polymerization in Emulsion, Dispersion, and Other Microstructured Fluids;

- Symp. 7: Powder Metallurgy and
Particulate Systems;

- Symp. 8: Ceramic and Composite Materials; - Symp. 9: Functional Polymers: Mixtures and Alloys;

- Symp. 10: Microbeam Analysis in Materials Characterization;

- Symp. 11: General Research Progress in Materials Science;

- Symp. 12: Structural Materials: Fabrication and Applications;

- Symp. 13: Materials Issues in Corrosion; - Symp. 14: Materials Research Opportunities in Industry and Services;

- Symp. 15: Computational Materials Science: Theory and Simulation of Nanostructured Materials;

- Symp. 16: Educational Trends in Materials Science;

- Symp. 17: Vacuum and Surface Science;

- Symp. 18: Microscopía Electrónica de Barrido y Técnicas de Imágenes;

- Symp. 19: Analytical Electron Microscopy;

- Symp. 20: Workshop on Advanced
Coatings Technology; and

- Symp. 21: Materials Science Aspects of Industrial Recycling.

Abstracts should be sent by July 30, 1996 to the symposium chair and to Lorenzo Martínez, General Chair, International Materials Research Congress Instituto de Física-Cuernavaca, A.P. 48-3, C.P. 62251, Cuernavaca, Morelos, México; phone 73138915, 175388; fax 73-173077; or e-mail cancun96@ce.ifisicam.unam.mx.

Registration fees before June 30, 1996 are $\$ 150, \$ 37.50$ for students; and after July 1, $1996 \$ 200$, and $\$ 50$ for students. The official languages will be Spanish and English.

For more information, contact the general chair or review the World Wide Web site: http://ifisicam.unam.mx/cancun96.html.

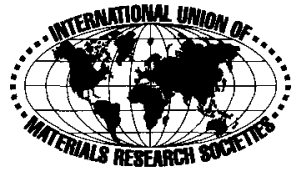

\section{IBMM-96 to Highlight Six Topics of International Interest}

The Tenth International Conference on Ion Beam Modification of Materials (IBMM96) is being held September 1-6, 1996 at the Hyatt Regency Hotel in Albuquerque, New Mexico, chaired by J.C. Barbour of Sandia National Laboratories and M. Nastasi of Los Alamos National Laboratory. It is being sponsored by Sandia National Laboratories and Los Alamos National Laboratory, and co-sponsored by the Materials Research Society. The emphasis of the conference is on the science of materials properties involving both fundamental processes and property changes occurring either during or subsequent to ion bombardment.

While covering the traditional topics of previous IBMM conferences, IBMM-96 will highlight those areas of specific concern to the U.S. materials research effort and are currently of prime interest to the international community. The six topics and preliminary list of their respective invited speakers are:

- Fundamentals/Basics of Ion-Solid Interactions: damage formation, defects, sputtering, ion mixing, phase transformations, amorphization, crystallization. (R.S. Averback - United States); - Modeling, Simulation, and Theory: molecular dynamics, Monte-Carlo, and analytical descriptions of ion-solid interactions and ion beam modification of materials. (W. Moeller-Germany);

- Ion Beam Processing of Optical and Electronic Materials: ion beam processing of semiconductor materials, semiconductor devices, ion beam synthesis and modification of waveguide and optical materials. (M.I. Current-United States and S. Coffa-Italy);

- Ion Beam Synthesis and Modification of Metals, Ceramics, and Insulators: novel materials and property changes in metals, ceramics, polymers, and superconductors exposed to ion bombardment. (C.W. White-United States and W.J. Ensinger-Germany);

- Ion Beam Synthesis and Processing with Plasmas and Low Energy Ion Beams: plasma-based implantation, deposition, and etching; ion-beam assisted deposition. (N.W. Cheung-United States); and - Applications: mechanical and tribological properties, corrosion and catalysis, electrical and optical properties; industrial, defense, and energy technologies. (J-P. Hirvonen-Finland).

The proceedings will be published by Elsevier Science Publishers B.V. in a special issue of Nuclear Instruments and Methods in
Physical Research, Section B: Beam Interactions with Materials and Atoms.

Companies who are interested in exhibiting product lines or sponsoring receptions and refreshment breaks at IBMM-96 should contact Mary E. Kaufold, Materials Research Society, $9800 \mathrm{McKnight}$ Road, Pittsburgh, PA 15237; 412-367-3036; fax 412367-4373, or e-mail Kaufold@mrs.org.

For meeting registration and hotel reservation forms, contact the Conference and Visit Management group, LeeRoy Herrera, 505-665-5593, e-mail Ljherrera@LanL.gov. The full registration fee covers attendance to all sessions; a book of abstracts and proceedings; the welcome reception on Sunday, September 1; daily refreshments and luncheons; and an outing on Wednesday, September 4 . The conference fee received by July 1, 1996, in U.S. dollars, is \$450; received after July 1, 1996, $\$ 500$; and for students, $\$ 300$, which does not include a copy of the proceedings. The deadline for hotel reservations is July 30, 1996. Further information on the conference can be accessed on the World Wide Web at http://www.sandia.gov/ IBMM96/IBMM96.html, using full upperand lower-case letters as given. 